\title{
Feiasibility Study of Direct Admitting of Pongamia Oil in I.C Engines
}

\author{
S. Ramkumar ,V.Kirubakaran* \\ Rural Energy Center, Gandhigram Rural Institute, Deemed University Gandhigram, India
}

Copyright $@ 2015$ Horizon Research publishing all rights reserved.

\begin{abstract}
The increase in global warming, pollution due to the combustion of fossil fuels and its uneven distribution leads for the search of alternative energy source. Only few of them have done research with direct admitting of vegetable oil in C.I engine and this is due to reason of very high viscosity, lower heating value, low volatility and higher freezing point of vegetable oil. While in direct admitting of vegetable oil in C.I engines most of the authors says that the performance and emission characteristics depend on the viscosity, flash point, fire point, calorific value, density, cetane number. This paper reviews the characteristics of various non-edible vegetable oils, its performance and emission characteristics in C.I engines during direct admitting of vegetable oil. The yield of oil from a plant is an important factor in reliability of the fuel so some of the non-edible oil yielding plants, its yield and soil preference are also reviewed. From the review it can be concluded that non-edible oil could be a good alternative fuel which have a good reliability of oil production but direct admitting of vegetable oil for long term may reduce the engine life.
\end{abstract}

Keywords C.I Engine, Pongamia Oil, Performance, Emission, Non-edible Oil

\section{Introduction}

The first C.I engine is designed to run with vegetable oil as fuel [1], but Due to the easy availability of fossil diesel fuel the engines produced are designed for the usage of the fossil diesel fuel. Fossil fuels are depleted each and every day and it's not an easy job to regenerate the fossil fuels. Most of the mineral oils produced are being used in I.C engines. Fossil fuels are conventional energy sources but it is non-renewable. After depletion of fossil fuel the demand for it is going to be higher and costlier and it may be used only for aviation purpose. To meet the tomorrow's energy demand vegetable oil could be a good alternative resource.

The carbon produced during the combustion of vegetable oil is recyclable. The vegetable oil used as fuel for I.C engine should be reliable, easily available and have better enough to run in I.C engine should be reliable easily available, and have better physical and chemical properties.

From various studies of journals and reports it can be found that Pongamia oil is a feasible one to be used in C.I engines. The engine specified below is fueled with Pongamia oil, its performance and emission test were conducted and compared with diesel fuel as base fuel.

\section{Literature Review in Direct Admitting of Vegetable Oil in Conventional Engine without any Modification}

k.Pramanik[22] used Jatropha oil as fuel and compared its performance with diesel. The result shows that the brake specific fuel consumption for Jatropha oil is higher than diesel because of the relative fuel density, viscosity and heating value. The Exhaust gas temperature for Jatropha oil is higher than diesel. The brake thermal efficiency of Jatropha oil is lesser than diesel, this shows that less fuel is converted into work and the remaining fuel is emitted as heat [22].

During direct admitting of the Jatropha oil at constant speed of $1500 \mathrm{rpm}$ C.I engine, the Brake Specific Fuel Consumption for Jatropha oil is higher than diesel. This is because of the lower calorific value of the Jatropha oil. The higher viscosity leads to poor atomization and larger fuel droplet of Jatropha than the diesel results in lesser Brake Thermal Efficiency. The exhaust gas temperature for Jatropha oil is lesser than diesel. The smoke opacity, $\mathrm{CO}_{2}$, $\mathrm{CO}$ and $\mathrm{HC}$ for Jatropha oil is higher when compared to diesel fuel [23].

M.S.shehata, S.M.Abdel Razek[25] uses a constant speed diesel engine and use sunflower oil as fuel. Its performance and emission characteristics are compared with diesel as base fuel .The brake thermal efficiency for sunflower oil is lesser than diesel .The higher density and lower heating value of sunflower oil when compare to diesel leads to lower brake thermal efficiency, so it results in lesser cylinder 
pressure for sunflower oil. The $\mathrm{CO}$ emission is higher for sunflower oil than the diesel [25].

k.Purushothaman, G.Nagarajan [26] used a single cylinder C.I engine. They used orange peel oil as fuel. The peak cylinder pressure produced during the usage of orange oil is about 75 bar where as diesel have only 71 bar this is because of the higher oxygen content in the orange peel oil. The maximum heat release rate at peak load for orange peel oil is $52 \mathrm{~J} /{ }^{\circ} \mathrm{CA}$ and for diesel is $39 \mathrm{~J} /{ }^{\circ} \mathrm{CA}$. The brake thermal efficiency for orange peel oil is $30.7 \%$ and for diesel is $29.3 \%$. The NOx for orange peel oil is $19.99 \mathrm{~g} / \mathrm{kWh}$ and for diesel is $14.99 \mathrm{~g} / \mathrm{kWh}$. The presence of Oxygen in orange oil leads to higher NOx than the diesel. As the engine load increases the $\mathrm{CO}$ increases.

The $\mathrm{CO}$ emission for orange oil is lesser than diesel because orange oil has $3 \%$ of oxygen content by weight. The $\mathrm{HC}$ emission for orange peel oil is lesser than diesel. The combustion quality is better for orange peel oil than the diesel so the smoke level is lesser for orange peel oil.[26]
The direct admitting of karanja oil in diesel engine leads to lower brake thermal efficiency than the diesel fuel. It's because of the larger droplet size of the fuel. The brake specific fuel consumption of karanja oil is higher than Diesel where Brake specific energy consumption for karanja oil is almost equal to that of diesel. $\mathrm{CO}$ emission is higher for karanja oil than diesel. HC for karanja oil is lower than diesel at lower load, higher than diesel at higher load. NOx is significantly lower for karanja oil but the gap decreases at higher load. The exhaust gas temperature is higher for karanja oil but the NOx is lower than diesel because large amount of heat is released at late combustion phase.

The poor atomization of karanja oil leads to higher smoke opacity than diesel. With increase in load the smoke opacity increases [27].

With the direct admitting of mustard oil in C.I engine the smoke opacity, $\mathrm{CO}$ emission, Hydrocarbon emission and NOx for mustard oil is lesser than diesel. The Particulate matter is lesser for diesel than the mustard oil[28].

Table 1. Properties of various Non-Edible Plants and Its oil properties

\begin{tabular}{|c|c|c|c|c|c|c|c|}
\hline Plant Name & Rubber & Soapnut Oil & Neem & Eucalyptus Oil & Poon Oil & Pongamia Pinnata & Rape Seed Oil \\
\hline Rain Fall (mm) & & & $750-1000[2]$ & & & $500-2500[2]$ & \\
\hline Temperature $\left({ }^{\circ} \mathrm{C}\right)$ & & & $15-45[2]$ & & & & \\
\hline Soil Preference & & $\begin{array}{l}\text { Deep Loamy } \\
\text { And Leached }\end{array}$ & Deep Clay[2] & & & Wide Range[2] & \\
\hline Height (m) & $34[2]$ & & $20[2]$ & & & $8-10[2]$ & \\
\hline Seed Yeild $(\mathrm{Kg} / \mathrm{ha} /$ year $)$ & $150[2]$ & & 12 to $20[2]$ & & & $900-9000[2]$ & \\
\hline Oil Content In & $40-50[3]$ & $51[3]$ & \multirow{2}{*}{$33-45[3]$} & & & \multirow{2}{*}{$\begin{array}{c}30 \text { to } 40[2], \\
33[3]\end{array}$} & \\
\hline Seed $(\%)$ & $40-50[2]$ & $23[2]$ & & & & & \\
\hline Calorific Value $\mathrm{MJ} / \mathrm{Kg}$ & $\begin{array}{l}37.5[4,5] \\
37.25[6]\end{array}$ & $38.207[7]$ & $29.27[2]$ & $43.27[10]$ & $39.65[11,12]$ & $34[4],[13],[5]$ & $\begin{array}{c}40.11[17,12] \\
3762[18]\end{array}$ \\
\hline Cloud Point $\left({ }^{\circ} \mathrm{C}\right)$ & & $14.2[7]$ & & & & & \\
\hline Poure Point $\left({ }^{\circ} \mathrm{C}\right)$ & & $6.5[7]$ & & & $-5[11]$ & $-3[14]$ & \\
\hline Fire Point $\left({ }^{\circ} \mathrm{C}\right)$ & $210[6]$ & & & & & $\begin{array}{c}258[27,12], \\
230[14]\end{array}$ & \\
\hline Flash Point $\left({ }^{\circ} \mathrm{C}\right)$ & $198[4,5,6]$ & $232[7]$ & & $54[10]$ & $158[11],[12]$ & $\begin{array}{c}205[4], 242[13], \\
237[27][12], \\
263[5], 225[14], \\
215[15]\end{array}$ & $\begin{array}{c}234[17], \\
280[5], \\
234[12], \\
246[33]\end{array}$ \\
\hline Viscosity & $66.2[4,5]$ & $1612[7$ & & $1621[101$ & $407[11$ 1 & $27.84[4,13], 35.98[27]$, & $31.23[17,12]$ \\
\hline @ $40^{\circ} \mathrm{C} \mathrm{cSt}$ & $66[6]$ & (7) & & $1.0-2.1[10]$ & 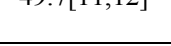 & $37.12[5], 35.98[12]$ & \\
\hline Density $\mathrm{Kg} / \mathrm{m}^{3}$ & & 904 [7] & & & $9264[11]$ & $\begin{array}{c}938[27], 924[14], \\
0.926[15]\end{array}$ & $914[18]$ \\
\hline Cetane Number & & & $31[9]$ & & & $46[13], 42[14], 31.8[15]$ & $37.6[18]$ \\
\hline Specific Gravity & $0.91[4,6,5]$ & & $0.968[9]$ & & $0.9264[12]$ & $\begin{array}{c}0.913[4], 0.912[5], \\
0.93[12], 0.925[14]\end{array}$ & $0.903[12]$ \\
\hline
\end{tabular}


Table 1. (Continues) Properties of various Non-Edible Plants and Its oil properties

\begin{tabular}{|c|c|c|c|c|c|c|c|}
\hline Plant Name & Jojaba & Honne & Polanga & Croton & Mahua & Jatropha & Cotton \\
\hline Rain Fall (mm) & & & & & $550-1500[2]$ & $\begin{array}{l}480-2400[2], \\
250-1200[2]\end{array}$ & \\
\hline Temperature $\left({ }^{\circ} \mathrm{C}\right)$ & & & & & & $20-28[2]$ & \\
\hline Soil Preference & & & & & Deep Clay[2] & Any Type[2] & \\
\hline Height (m) & & & & & $18-20[2]$ & $3-5[2], 5-7[2]$ & \\
\hline Seed Yeild (ton/hac/year) & & & & & & 0.1 to8 $[2]$ & \\
\hline Oil Content In Seed \% & & & & & $30-40[3]$ & $43-59[2], 30-50[3]$ & \\
\hline Calorific Value (MJ/Kg) & & $39.11[12]$ & $39.25[4]$ & $36.98[20]$ & $37.614[12]$ & $38.5[4,22], 39.7[21]$ & $39[4]$ \\
\hline Cloud Point $\left({ }^{\circ} \mathrm{C}\right)$ & $16[19]$ & & & & & & \\
\hline Poure Point $\left({ }^{\circ} \mathrm{C}\right)$ & $-6[19]$ & & & & & 3 to $5[30]$ & \\
\hline Fire Point $\left({ }^{\circ} \mathrm{C}\right)$ & & & & & $246[12]$ & 271 to 277 & \\
\hline Flash Point $\left({ }^{\circ} \mathrm{C}\right)$ & $186[12,19]$ & $224[12]$ & $221[4]$ & & $230[12]$ & $174[4], 210[22], 240[21]$ & $210[4]$ \\
\hline $\begin{array}{l}\text { Viscosity } \\
@ 40^{\circ} \mathrm{c} \text { Cst }\end{array}$ & $52[12,19]$ & $32.47[12]$ & $71.98[4]$ & $33.38[20]$ & $39.45[12]$ & $49.93[21]$ & $50[4]$ \\
\hline Density $\mathrm{Kg} / \mathrm{m}^{3}$ & & & & & & 932.9 [22], $918.6[21]$ & \\
\hline Cetane No. & $55[19]$ & & & $40.7[20]$ & & $38[22], 40-45[21]$ & \\
\hline Specific Gravity & $0.920[12]$ & $0.910[12]$ & $0.896[4]$ & & $0.924[12]$ & $0.920[21]$ & $0.912[4]$ \\
\hline
\end{tabular}

N.R.Banapurmatha, P.G. Tewaria, R.S. Hosmathb[29] used a constant speed C.I engine with injection timing of $27^{\circ} \mathrm{C}$ and with $80 \%$ load it is found that the ignition delay for diesel is $10^{\circ} \mathrm{CA}$ and for honge oil is $12^{\circ} \mathrm{CA}$. Were the cylinder pressure for diesel is about $71.5 \mathrm{bar}$ and 65 for honge oil. The combustion duration for Honge oil is higher than the diesel. Increase in the quantity of fuel injection leads to increase in power output but the duration of the combustion also get increases.

\section{Experimental Setup and Procedure}

\subsection{Instrumentation}

1) Digital temperature indicator to measure exhausts gas temperatures sensed by respective thermocouples.

2) Digital RPM indicator to measure the speed of engine.

3) Glass to measure the rate of fuel consumed during running through three way valve system.

4) Handheld stop clock for measuring quantity of fuel flow from burette.

5) Flue gas analyzer and gas analyzer used to measure the various emissions like $\mathrm{NO}, \mathrm{NO}_{2}, \mathrm{CO}, \mathrm{CO}_{2}$.

\subsection{Experimental Set Up}

The engine used for the investigation is a single cylinder, four stroke, constant speed, vertical, water cooled, direct injection diesel engine.

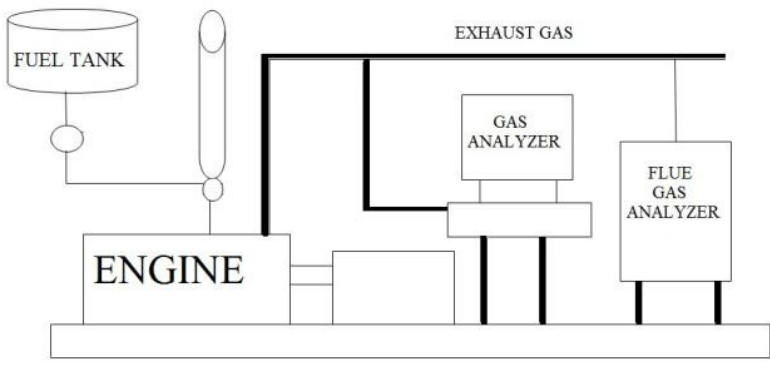

Figure 1. Experimental Setup

\subsection{Engine Specification:}

Table 2. Specification of Engine

\begin{tabular}{|c|c|}
\hline Manufacturer & Gujarat Forgings Pvt Ltd.. \\
\hline No of Cylinders & 1 \\
\hline Maximum Power & $8 \mathrm{HP}(5.9 \mathrm{KW})$ \\
\hline Compression Ratio & $17.5: 1$ \\
\hline Speed & $1500 \mathrm{RPM}$ \\
\hline SFC & $240 \mathrm{~g} / \mathrm{KWh}$ \\
\hline Lubrication oil & HD-30 \\
\hline Lubricating System type & Splash Type \\
\hline
\end{tabular}

\subsection{Valve Timing:}

Table 3. Valve Timing

\begin{tabular}{|c|c|}
\hline Inlet valve opening & $12^{0}$ Before TDC \\
\hline Inlet valve closing & $33^{0}$ After BDC \\
\hline Exhaust valve opening & $38^{0}$ Before BDC \\
\hline Exhaust valve closing & $13^{0}$ After TDC \\
\hline Injection timing & $28{ }^{\circ}$ Before TDC \\
\hline
\end{tabular}




\subsection{Emission Analyzer Specification:}

3.5.1. Flue gas analyzer Make: Landcom SeriesIII

Table 4. Specification of flue gas analyzer

\begin{tabular}{|c|c|c|c|c|}
\hline Sensor & $\begin{array}{c}\text { Standard } \\
\text { Range }\end{array}$ & $\begin{array}{l}\text { Max. } \\
\text { Range }\end{array}$ & Accuracy & Resolution \\
\hline Oxygen, $\mathrm{O}_{2}$ & $\begin{array}{l}0 \text { to } 25 \% \\
\text { Vol. }\end{array}$ & $\begin{array}{l}0 \text { to } \\
30 \% \\
\text { Vol. }\end{array}$ & $\pm 1 \%$ & $\pm 1 \%$ vol. \\
\hline $\begin{array}{l}\text { Carbon Monoxide, } \\
\text { CO(low) }\end{array}$ & $\begin{array}{l}0 \text { to } \\
2000 \\
\mathrm{ppm}\end{array}$ & $\begin{array}{l}0 \text { to } \\
100000 \\
\text { ppm }\end{array}$ & $\pm 2 \%$ & $\pm 1 \%$ \\
\hline $\begin{array}{c}\mathrm{CO}\left(\mathrm{H}_{2}\right) \\
\text { Compensated }\end{array}$ & $\begin{array}{l}0 \text { to } \\
2000 \\
\text { ppm }\end{array}$ & $\begin{array}{l}0 \text { to } \\
4000 \\
\text { ppm }\end{array}$ & $\pm 2 \%$ & $\pm 1 \%$ \\
\hline $\begin{array}{c}\text { Carbon Monoxide, } \\
\text { CO(high) }\end{array}$ & 0 to $4 \%$ & $\begin{array}{l}0 \text { to } \\
10 \%\end{array}$ & $\pm 2 \%$ & $\pm 1 \%$ \\
\hline $\begin{array}{c}\text { Sulphur Dioxide, } \\
\mathrm{SO}_{2}\end{array}$ & $\begin{array}{l}0 \text { to } \\
2000 \\
\text { ppm }\end{array}$ & $\begin{array}{l}0 \text { to } \\
50000 \\
\text { ppm }\end{array}$ & $\pm 2 \%$ & $\pm 1 \%$ \\
\hline Nitric Oxide, NO & $\begin{array}{l}0 \text { to } \\
1000 \\
\text { ppm }\end{array}$ & $\begin{array}{l}0 \text { to } \\
5000 \\
\text { ppm }\end{array}$ & $\pm 2 \%$ & $\pm 1 \%$ \\
\hline $\begin{array}{l}\text { Nitrogen Dioxide, } \\
\mathrm{NO}_{2}\end{array}$ & $\begin{array}{l}0 \text { to } 100 \\
\text { ppm }\end{array}$ & $\begin{array}{l}0 \text { to } \\
1000 \\
\text { ppm }\end{array}$ & $\pm 2 \%$ & $\pm 1 \%$ \\
\hline $\begin{array}{l}\text { Hydrogen Sulphide, } \\
\qquad \mathrm{H}_{2} \mathrm{~S}\end{array}$ & $\begin{array}{l}0 \text { to } 200 \\
\text { ppm }\end{array}$ & $\begin{array}{l}0 \text { to } \\
1000 \\
\text { ppm }\end{array}$ & $\pm 2 \%$ & $\pm 1 \%$ \\
\hline $\begin{array}{l}\text { Carbon Dioxide, } \\
\mathrm{CO}_{2}^{* *}\end{array}$ & $\begin{array}{l}0 \text { to } 25 \% \\
\text { vol. }\end{array}$ & - & $\pm 5 \%$ Vol. & $\begin{array}{l} \pm 0.1 \% \\
\text { Vol. }\end{array}$ \\
\hline Hydrocarbons, $\mathrm{C}_{\mathrm{x}} \mathrm{H}_{\mathrm{y}}$ & \multicolumn{4}{|c|}{0 to $5 \%$ Vol. (Application dependent) } \\
\hline $\begin{array}{c}\text { Flue gas } \\
\text { Temperature }\end{array}$ & \multicolumn{4}{|c|}{0 to $1000^{\circ} \mathrm{C}$} \\
\hline $\begin{array}{c}\text { Ambient } \\
\text { Temperature }\end{array}$ & \multicolumn{4}{|c|}{ Measured } \\
\hline Flow ( Velocity) & \multicolumn{4}{|c|}{1 to $50 \mathrm{~m} / \mathrm{s}$} \\
\hline
\end{tabular}

Note: Special ranges are available

\subsubsection{Gas Analyzer}

Make: Electronic System tech Model: PGA 13/ Portable Specifications:

Table 5. Specification of Gas analyzer

\begin{tabular}{|c|c|}
\hline \multirow{3}{*}{ Gas Range } & $\mathrm{CO}--0-50 \%$ \\
& $\mathrm{CO}_{2}-0-25 \%$ \\
& $\mathrm{CH}_{4}---0-10 \%$ \\
& $\mathrm{H}_{2}---0-50 \%$ \\
\hline Data logging & Yes \\
\hline
\end{tabular}

\subsection{Experimental Procedure}

The engine used in this experiment was a single cylinder direct injection diesel engine with a compression ratio of 17.5:1. The rated power was $3.7 \mathrm{~kW}$ at $1500 \mathrm{rpm}$. Test was carried out at constant speed of $1500 \mathrm{rpm}$. A drum brake dynamometer was coupled to the engine and measured the engine power.

The engine is allowed to run at constant speed and the experiment is conducted for different loads of $0 \%, 20 \%$, $40 \%, 60 \%, 80 \%$ and $100 \%$. First the engine is fueled with diesel, its performance and emission characteristics were analyzed, then the Pongamia oil is used as fuel and the performance and emission characteristics were analyzed. For both the diesel and Pongamia five set of readings were taken and the average reading was taken for performance and emission and it is plotted.

Exhaust gases were measured on line by a flue gas analyzer, in which $\mathrm{CO}, \mathrm{CO}_{2}, \mathrm{NOx}$ were analyzed with a non-dispersive infra-red (NDIR).

The engine was run to gain uniform speed after which was gradually loaded. The experiments were conducted for $0 \%, 20 \%, 40 \%, 60 \%, 80 \%$ and $100 \%$ load.

The engine was tested at constant speed for diesel and neat pongamia. The time taken for $10 \mathrm{cc}$ fuel was noted using stop watch. The $\mathrm{CO}, \mathrm{CO}_{2}$ and $\mathrm{NOx}$ emission were noted by using analyzer for each fuel. Finally the performance and emission characteristics were plotted in graph.

\section{Results and Discussions}

\subsection{Performance Characteristics}

The fig. 2 compares the Brake thermal efficiency of Diesel and Pongamia. The Brake Thermal Efficiency increases with increase in load. The similar trend of plot is seen for both the Pongamia and diesel. For Pongamia oil $80 \%$ to $100 \%$ load there is drop in efficiency. To maintain the speed of the engine more amount of fuel is injected at higher loads. The higher viscosity and lower volatility of Pongamia oil leads to lesser combustion quality than diesel so that the conversion rate of the fuel into energy is reduced, this leads to lesser BTE at $100 \%$ load than $80 \%$ load [16].

Brake Specific fuel consumption is the consumption of unit mass of fuel for producing unit power in a unit time. The fig. 3 shows sharp decrease in specific fuel consumption with increase in load because the need of fuel with the increase in brake power is considerably lesser due to lesser heat loss at higher load [24]. Because of the lower calorific value of Pongamia oil to maintain the constant speed for the particular load when compared to diesel it, requires more amount of fuel so the governor adjust and send more amount of fuel to the injector and hence more amount of fuel is injected. Specific Fuel Consumption for

\section{BTE Vs LOAD\%}

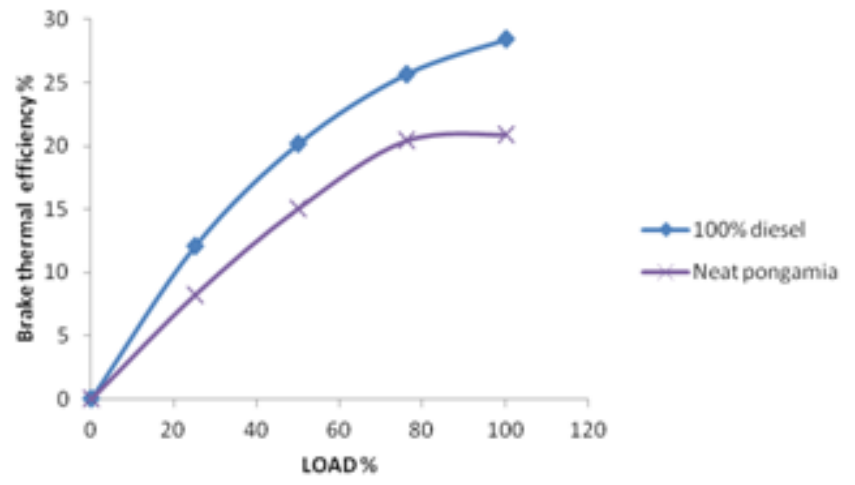

Figure 2. Variation of Brake Thermal Efficiency with load for Diesel and Pongamia oil 


\section{SFC Vs LOAD $\%$}

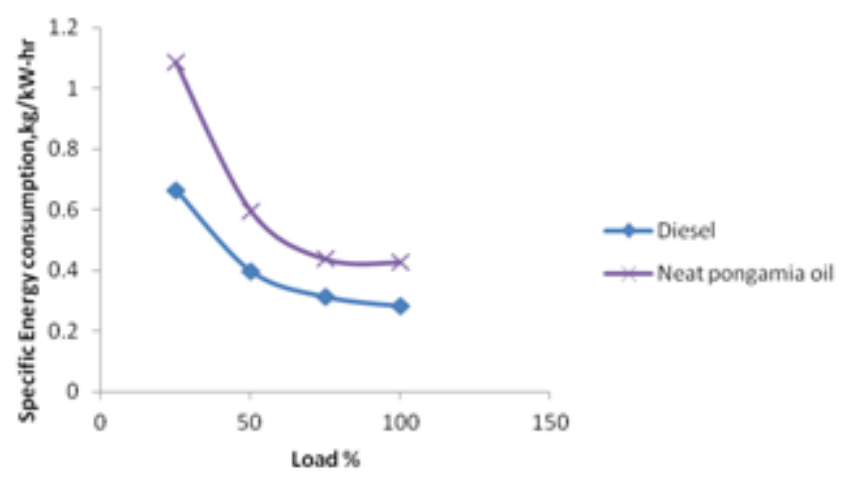

Figure 3. Variation of Specific fuel consumption with load for Diesel and pongamia oil

\section{TFC Vs BP}

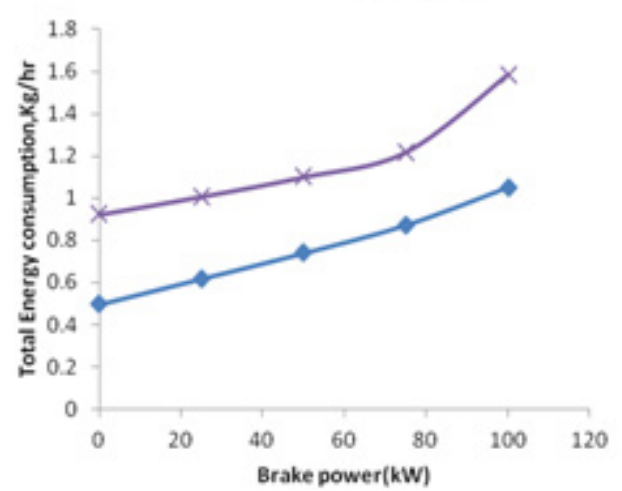

Figure 4. Variation of Total Fuel Consumption with Load for Diesel and Pongamia oil.

Pongamia is greater than diesel because the combustion character is lesser than diesel. Higher viscosity of Pongamia leads to poor atomization during injection of the fuel which results in larger droplet size of the fuel. The larger droplet size results incomplete combustion and the whole particle can't take place in combustion. When the fuel particle size is large the surface contact area with the air is lesser so it leads to lesser participation of the fuel in combustion. This may leads to higher SFC for Pongamia than diesel.

Total fuel consumption is the unit mass of the fuel consumed for unit time. From total fuel consumption the quantity of fuel consumed can be understood. The fig. 4 shows the total fuel consumption for both diesel and Pongamia oil. To maintain constant engine speed the governor is designed in such a way that it supplies fuel according to the engine load such that it supply more amount of fuel at higher load and lesser fuel at lower load.

\subsection{Emission Characteristics}

The $\mathrm{CO}$ emission for neat Pongamia is higher than diesel for all loads. The CO formation is due to the insufficient oxygen during the combustion process.

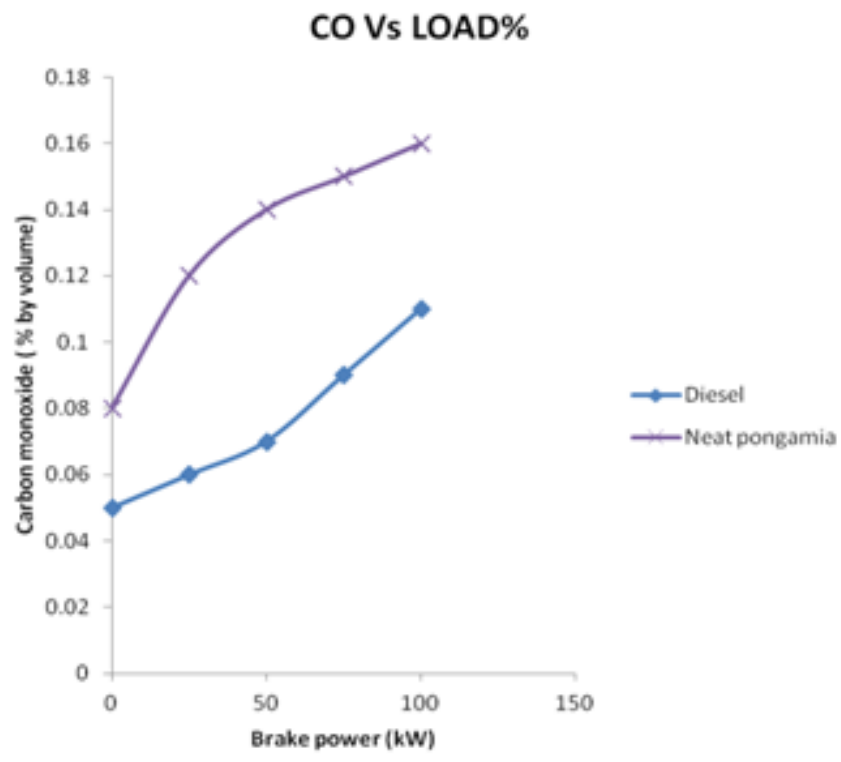

Figure 5. Variation of Carbon monoxide with Load for Diesel and Pongamia oil

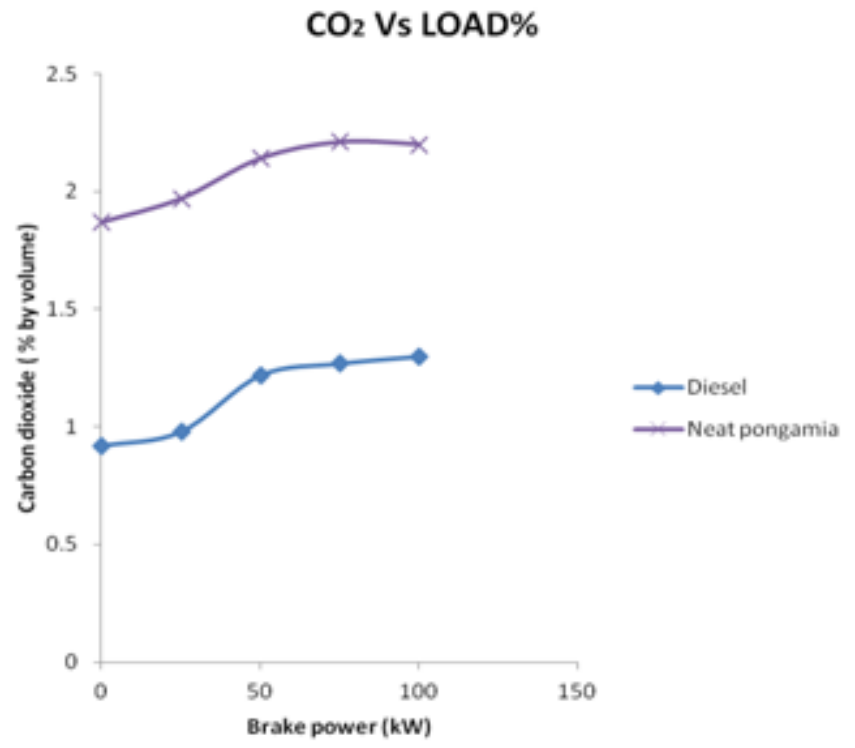

Figure 6. Variation of Carbon dioxide with Load for Diesel and Pongamia oil

\section{Nox Vs LOAD\%}

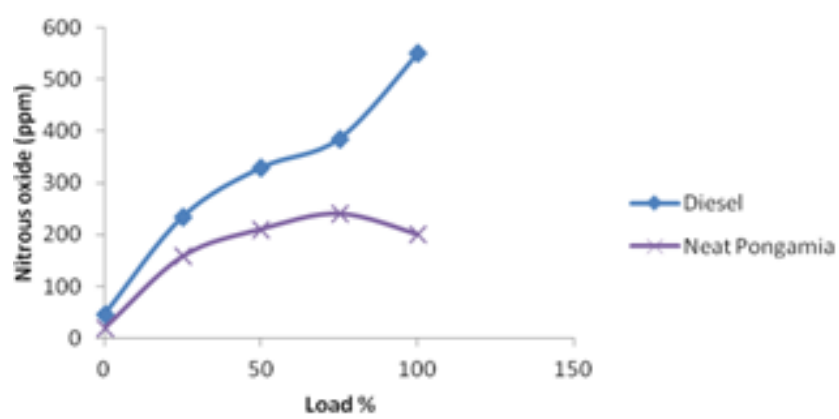

Figure 7. Variation of Nitrous oxide with Load for Diesel and Pongamia oil 


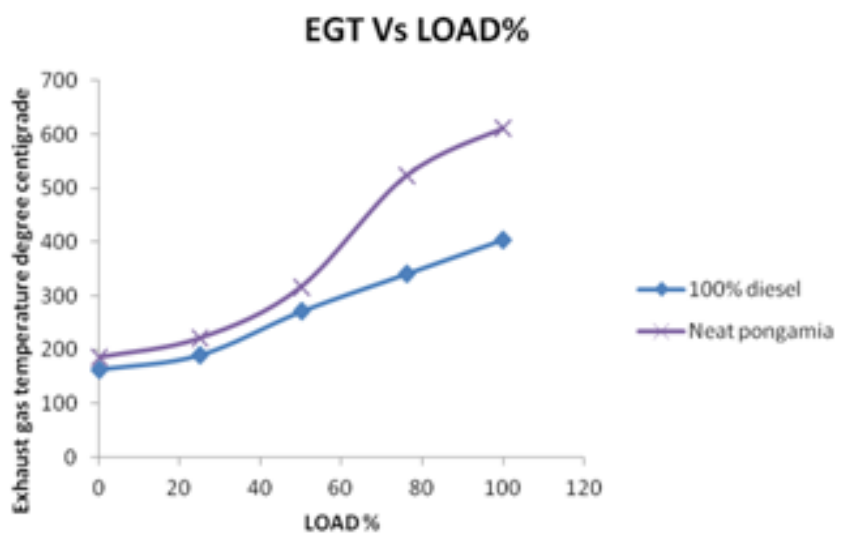

Figure 8. Variation of Exhaust Gas Temperature with Load for Diesel and Pongamia oil

The insufficient oxygen during the combustion leads to the formation of $\mathrm{CO}$ [8]. Even though the vegetable oil contains oxygen, the higher viscosity of vegetable oil leads to poor atomization therefore the inner layer of the fuel droplet may not have sufficient oxygen during the combustion, this may leads to the higher $\mathrm{CO}$ in vegetable oil.

The $\mathrm{CO}_{2}$ emission for Pongamia is higher than diesel due to the presence of oxygen content in the Pongamia oil. The NOx is lesser for Pongamia oil than the diesel. This is because of higher viscosity of Pongamia which results in poor combustion. NOx formation depends on the temperature during the combustion.

Even though the NOx for Pongamia is lesser than diesel, the exhaust gas temperature for Pongamia is higher than diesel. This indicates that the combustion takes place at controlled combustion phase. The heat released cannot be significantly used for raise in pressure because the release of heat takes place almost during the middle of the expansion stroke of the engine.

\section{Conclusions}

The engine can be successfully operated using Pongamia oil as fuel. The efficiency at $80 \%$ load is $24.65 \%$ and for $100 \%$ load is $21.59 \%$. From the experimental study we can conclude that the combustion of Pongamia oil is better around $80 \%$ load. A slight higher vibration and knocking is seen while using Pongamia. The performance and emission characteristics while using Pongamia may be Slightly inferior in direct admitting but it can be used in rural areas and pumping applications. By slight modifications of fuel or the engine, Pongamia can be used for long term and the vibration and knocking can be reduced. Pongamia is a nitrogen fixing plant so the commercial oil production leads to a source of income for rural people and the quality of life will be improved.

\section{Nomenclature}

BTE-Brake Thermal Efficiency

SFC- Specific Fuel Consumption

TFC- Total Fuel Consumption

CO-Carbon monoxide

$\mathrm{CO} 2$-Carbondioxde

NOx- Nitric oxide

TDC-Top Dead Center

BDC-Bottom Dead Centre

\section{REFERENCES}

[1] Knothe G.Van Gerpan, J.Krahl J.Editors, The history of vegetable oil- based diesel fuels, In:The biodiesel hand book-2005.

[2] A.E.Atabani, A.S.Silitonga, H.C.Ong

T.M.I.Mahlia,H.H.Masjuki, Irfan Anjum, Badruddin, H.Fayaz, Non-Edible vegetable oils: A Critical evaluation of oil extraction, fatty acid compositions, biodiesel production, characteristics, engine performance and emission production, Renewable and sustainable Energy review 18(2013)211-245.

[3] Basumatary Sanjay, Non-Conventional Seed Oils as Potential Feedstocks for Future Biodiesel Industries: A Brief Review, Research Journal of Chemical Sciences, ISSN 2231-606X Vol. 3(5), 99-103, May (2013) Res. J. Chem. Sci.International Science Congress Association 99 Review Paper.

[4] P.K.Sahoo, L.M. Das , M.K.G. Babu, S.N. Naik Biodiesel development from high acid value polanga seed oil and performance evaluation in a $\mathrm{CI}$ engine.

[5] K.Sureshkumara, R.Velrajb, R.Ganesana, Performance and exhaust emission characteristics of a CI engine fueled with Pongamia pinnata methyl ester (PPME) and its blends with diesel, Renewable Energy 33 (2008) 2294-2302.

[6] A.S. Ramadhas, S.Jayaraj, C.Muraleedharan, Dual fuel mode operation in diesel engines using renewable fuels: Rubber seed oil and coir-pith producer gas, Renewable Energy 33 (2008) 2077-2083

[7] R.D. Misra, M.S. Murthy, Performance, emission and combustion evaluation of soapnut oil-diesel blends incompression ignition engine, Fuel 90 (2011) 2514-2518

[8] John B. Hey wood, Internal Combustion Engine Fundamentals.

[9] K. Anbumani and Ajit Pal Singh, performance of mustard and neem oil blends with diesel fuel in C.I. engine, VOL. 5, NO. 4, APRIL 2010 ISSN 1819-6608 ARPN Journal of Engineering and Applied Sciences C2006-2010 Asian Research Publishing Network.

[10] Tamilvendhan.D, Ilangovan.v, Performance, emission and combustion characteristics of a methyl ester sunflower oil, eucalyptus oil in a single cylinder air cooled and direct injection diesel engine, International Journal of Engineering Science and Technology. 
[11] P.K.Devan, N.V.Mahalakshmi, Study of the performance, emission and combustion characteristics of a diesel engine using poon oil-based fuels, Vegetable property Fuel Processing Technology 90 (2009) 513-519.

[12] D. Subramaniam a,n, A.Murugesan b, A.Avinash a, -A.Kumaravel, Bio-diesel production and its engine characteristics-An expatriate view , Renewable and Sustainable Energy Reviews 22 (2013) 361-370.

[13] S. Jaichandar, K. Annamalai, Effects of open combustion chamber geometries on the performance of pongamia biodiesel in a DI diesel engine, Fuel 98 (2012) 272-279.

[14] Bobade and Khyade, International Science Congress Association Detail studies on the Properties of Pongamia Pinnata (Karanja) for the Production of Biofuel, Research Journal of Chemical Sciences ISSN 2231-606X Vol. 2(7), 16-20, July (2012) Res.J.Chem.Sci.

[15] P. K. Bose, R. A. Beg, B. B. Ghosh, R. K. Chakrabarti and Subodh Kr. Saha, Performance and Emissions Characteristics of a Naturally Aspirated Diesel Engine with Esterified Vegetable Oil, SAE technical paper series 2001-01-3386,Volume 7: Emissions and Fuels(P-373)

[16] Md Nurun Nabi, Md Shamim Akhter, Md Atiqur Rahman, Waste transformer oil as an alternative fuel for diesel engine,Procedia Engineering 56 ( 2013 ) 401 - 406, Published by Elsevier Ltd. 5th BSME International Conference on Thermal Engineering

[17] Hanbey Hazar, Huseyin Aydin, Performance and emission evaluation of a CI engine fueled with preheated raw rapeseed oil (RRO)-diesel blends,Applied Energy 87 (2010) 786-790.

[18] A.S. Ramadhas, S. Jayaraj, C. Muraleedharan, Use of vegetable oils as I.C. engine fuels-A review, Renewable Energy 29 (2004) 727-742.

[19] M.S. Shehata, S.M. Abdel Razek, Experimental investigation of diesel engine performance and emission characteristics using jojoba/diesel blend and sunflower oil, Fuel 90 (2011)886-897.

[20] Frank Lujaji a, Lukács Kristóf b, Akos Bereczky b, Makame Mbarawa, Experimental investigation of fuel properties, engine performance, combustion and emissions of blends containing croton oil, butanol, and diesel on a CI engine, Fuel 90 (2011) 505-510.
[21] M. Senthil Kumar, A. Ramesh and B. Nagalingam, Experimental Investigations on a Jatropha Oil Methanol Dual Fuel Engine, SAE TECHNICAL PAPER SERIES 2001-01-0153.

[22] K. Pramanik, Properties and use of jatropha curcas oil and diesel fuel blends in compression ignition engine, Renewable Energy 28 (2003) 239-248.

[23] Deepak Agarwal, Avinash Kumar Agarwal, Performance and emission characteristics of Jatropha oil (pre heating and blends) in a direct injection compression ignition. Applied thermal engineering 27(2007)2314-2323.

[24] J.Isaac joshua Ramesh Lalvani, M.Parthasarathi, Performance improvement in a single cylinder Diesel engine powered with pongamia Biodiesel by incorporationg swirling grooves. Advanced materials research vol. 768920130 pp119-205.

[25] M.S.shehata, S.M.Abdel Razek, Experimental Investigation of Diesel engine performance and emission characteristics using jajoba (Diesel Blends and sunflower oil), Fuel 90(2011)886-897.

[26] K. Purushothaman, G. Nagarajan, Experimental investigation on a C.I. engine using orange oil and orange oil with DEE, Fuel 88 (009) 1732-1740.

[27] Avinash kumar Agarwal, K.Rajamohan, Experimental Investigation of Performance and Emission of Karanja oil and its blend in a single cylinder agriculture diesel engine, Applied energy 86(2009)106-112.

[28] A.Sanjid, H.H.Masjuki, M.A.Kalam, S.M.Ashrafur Rahman, M.J.Abedin, S.M.Palash, Impact of palm, mustard, waste cooking oil and Calophyllum in ophyiium biofuels on performance and emission on C.I engines. Renewable and sustainable energy reviews 27(2013)664-682

[29] N.R. Banapurmatha,, P.G. Tewaria, R.S. Hosmath, Experimental investigations of a four-stroke single cylinder direct injection diesel engine operated on dual fuel mode with producer gas as inducted fuel and Honge oil and its methyl ester (HOME) as injected fuels, Renewable Energy 33 (2008) 2007-2018

[30] Deepak Agarwal, Avinash Kumar Agarwal, Performance and emissions characteristics of Jatropha oil (preheated and blends) in a direct injection compression ignition engine, Applied Thermal Engineering 27 (2007) 2314-2323 